\title{
IMAGE IN DERMATOLOGY
}

\section{Pitted Keratolysis}

Received/Recebido 2021/03/01

Accepted/Aceite 2021/06/10

Published/Publicado $2021 / 09 / 30$

\section{Queratólise Puntacta}

Telma Luís* ${ }^{*}$, Ana Goicoechea² $\odot$, Miriam García ${ }^{3}$ ○

'Serviço de Pediatria, Centro Hospitalar do Baixo Vouga,Aveiro, Portugal

${ }^{2}$ Centro de Salud de Sárdoma, Estructura Oganizativa de Xestión Integrada (EOXI) de Vigo, Vigo, Pontevedra, España

${ }^{3}$ Centro de Salud de Sárdoma, Estructura Oganizativa de Xestión Integrada (EOXI) de Vigo, Vigo, Pontevedra, España

KEYWORDS - Pitted keratolysis, bacterial skin infection.

PALAVRAS-CHAVE - Queratólise puntacta, infeção cutânea bacteriana.

A healthy 13-year-old non-atopic male presented with a month history of malodorous and slightly itchy skin lesions over both soles associated with hyperhidrosis. The patient used almost permanently occlusive footwear. On physical examination, we observed multiple yellowish-brown crateriform pits with punched out appearance and overlying thin scales associated with erosive areas coalescing on the metatarsal region of the plantar surface of both feet (Fig. 1). Non-pressure bearing areas were spared. Based on the clinical history and cutaneous findings, the patient was diagnosed with pitted keratolysis. Avoidance of occlusive footwear was recommended and topical mupirocin twice daily was prescribed for two weeks, with clinical resolution.

\section{DISCUSSION}

Pitted keratolysis (PK) is a relatively frequent superficial bacterial skin infection that typically affects pressure-bearing areas of the soles. ${ }^{1-5}$ Etiological agents include Corynebacterium spp, Micrococcus sedentarius, Dermatophilus congolensis, Streptomyces, and Actinomyces keratolytica. ${ }^{3-5}$ These bacteria produce proteases that digest keratin and destroy the stratum corneum, resulting in the characteristic crateriform pitting and erosions. ${ }^{3,5}$ A malodorous foot odour occurs due to sulfur compounds produced by causal microorganisms, but it is not always present. ${ }^{5}$ Most cases are asymptomatic, although pruritus and a burning or pain sensation may occur on walking..$^{2-5}$ Predisposing factors include hyperhidrosis, prolonged use of occlusive footwear, humid climate, poor foot hygiene, obesity, diabetes mellitus and immunodeficiency. ${ }^{2-5}$ Adolescents and young adults are more commonly affected. ${ }^{5}$ There is no racial predilection, but there is a male predominance, presumably due to males' frequent use of occlusive footwear. ${ }^{2,5}$ The diagnosis is clinical. ${ }^{3,5}$ Main differential diagnosis include plantar warts and tinea pedis., ${ }^{1,3}$ Topical antibiotic therapy, such as clindamycin, erythromycin, mupirocin or fusidic acid, twice daily, usually leads to resolution in 2 to 4 weeks. ${ }^{3,5}$ Topical benzoyl peroxide is an alternative first-line treatment. ${ }^{5}$ Oral antibiotics are reserved for resistant cases. ${ }^{4,5}$ Additional measures, such as treatment of concomitant hyperhidrosis and improving foot hygiene, promote clinical resolution and reduce the risk of reinfection. ${ }^{2,5}$

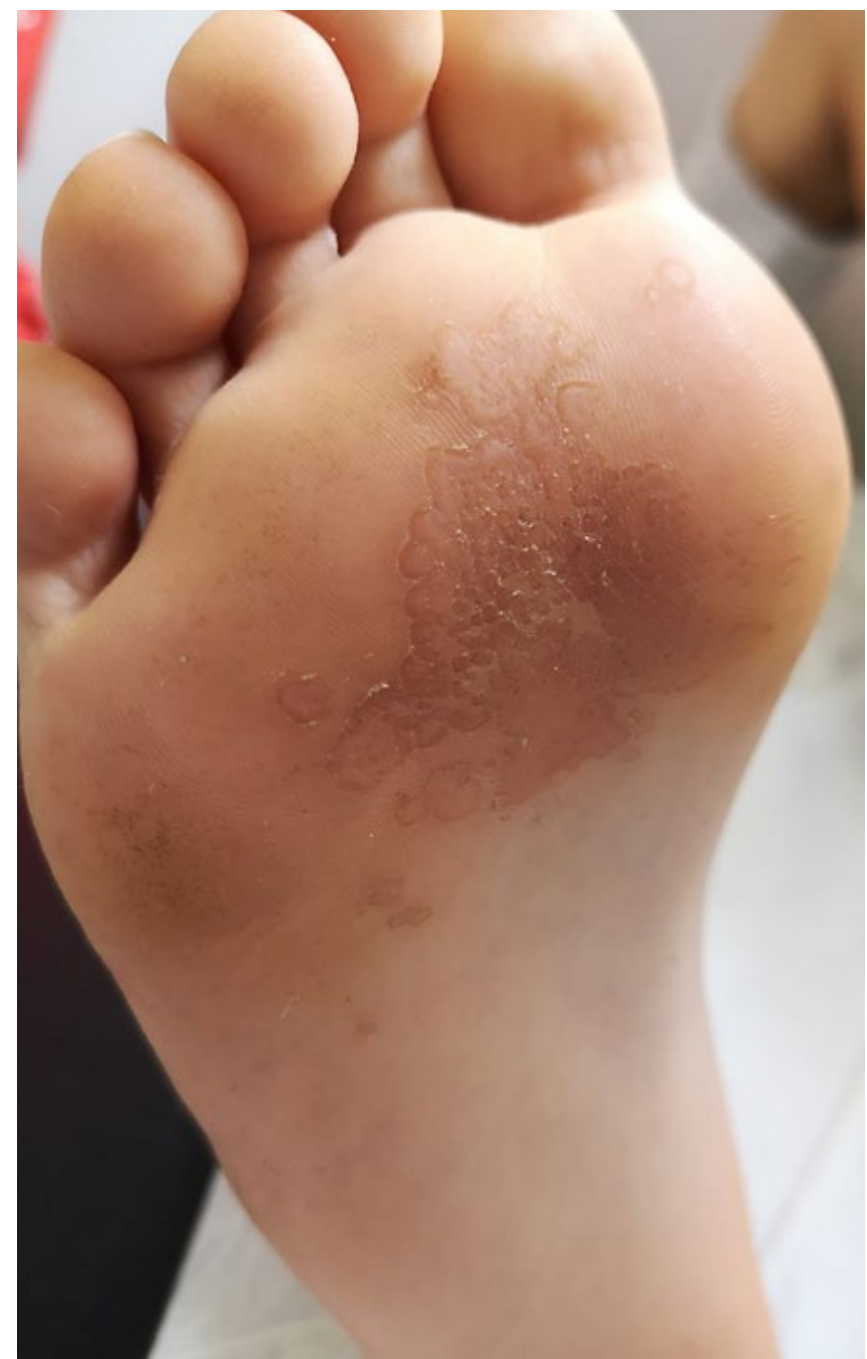

Figure 1 - Multiple yellowish-brown crateriform pits and erosive areas on metatarsal region of the plantar surface of the right foot. 
Conflicts of Interest: The authors have no conflicts of interest to declare. Financing Support: This work has not received any contribution, grant or scholarship. Confidentiality of Data: The authors declare that they have followed the protocols of their work center on the publication of data from patients. Patient Consent: Consent for publication was obtained. Provenance and Peer Review: Not commissioned; externally peer reviewed.

Conflitos de Interesse: Os autores declaram a inexistência de conflitos de interesse na realização do presente trabalho. Fontes de Financiamento: Não existiram fontes externas de financiamento para a realização deste artigo. Confidencialidade dos Dados: Os autores declaram ter seguido os protocolos da sua instituição acerca da publicação dos dados de doentes. Consentimento: Consentimento do doente para publicação obtido. Proveniência e Revisão por Pares: Não comissionado; revisão externa por pares.

\section{ORCID}

Telma Luís: https://orcid.org/0000-0002-5886-865X

Ana Goicoechea: https://orcid.org/0000-0002-4333-919X

Miriam García: https://orcid.org/0000-0002-6028-7483
Corresponding Author: Telma Luís

Address: Av. Artur Ravara, 3810-164 Aveiro, Portugal

E-mail: telmaluismarques@gmail.com

(c) Author(s) (or their employer(s)) 2021 SPDV Journal. Re-use permitted under CC BY-NC. No commercial re-use.

(c) Autor (es) (ou seu (s) empregador (es)) 2021 Revista SPDV. Reutilização permitida de acordo com CC BY-NC. Nenhuma reutilização comercial.

\section{REFERENCES}

1. Sil A, Bhanja DB. Pitted Keratolysis. Indian Pediatr. 2020;57:875

2. Law RW, So E, Chu AK, Logan DB. Pitted Keratolysis: a case report and review of current literature. Proc Singapore Healthcare. 2019;28: 71-73. doi 10.1177/2010105818767167.

3. Gamage M. Pitted Keratolysis: an incidental finding in a 10 year old girl. Sri Lanka J Child Health. 2020; 49: 193-4.

4. de Almeida HL Jr, Siqueira RN, Meireles Rda S, Rampon G, de Castro LA, Silva RM. Pitted keratolysis. An Bras Dermatol. 2016;91:106-8. doi: 10.1590/abd1806-4841.20164096.

5. Barankin B, Leung AK. Pitted Keratolysis. UpToDate. [Accessed on December 15th, 2020] Disponivel em: http://www.uptodate.com. 